\title{
TPACK in ASEAN perspectives: Case study on Thai pre-service teacher
}

\author{
Prasart Nuangchalerm \\ Faculty of Education, Mahasarakham University, Thailand
}

\begin{tabular}{ll}
\hline \hline Article Info & ABSTRACT \\
\cline { 2 - 3 } Article history: & $\begin{array}{l}\text { Technological Pedagogical and Content Knowledge (TPACK) is now } \\
\text { recognizing for teacher development and preparation program. The new era } \\
\text { of teaching and learning are not only focus on contents, but also pedagogical } \\
\text { knowledge, technology and education with instructional strategies are now } \\
\text { Revised Sep 15, } 2020 \\
\text { Accepted Oct 20,2020 }\end{array}$ \\
$\begin{array}{l}\text { necessary for teacher preparation program. This study focuses on identifying } \\
\text { and summarizing the features of TPACK in ASEAN literatures. The review }\end{array}$ \\
was conducted using the ACI database; a total of 11 articles describing \\
TPACK based on specific search criteria. The framework of TPACK needs \\
to generalize to school policy, administrative purposes and teacher \\
development and teacher preparation program. Also, the exploratory TPACK \\
Pedagogy
\end{tabular}

This is an open access article under the $\underline{C C B Y-S A}$ license.

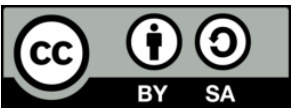

\section{Corresponding Author:}

Prasart Nuangchalerm,

Faculty of Education,

Mahasarakham University,

Muang Mahasarakham 44000, Thailand.

E-mail: prasart.n@msu.ac.th

\section{INTRODUCTION}

The new era of education is not now focusing on what to teach, but on how teacher teach and how students learn that are widely emphasized in school curriculum and instructional practices. Knowledge tends to be changed and rapidly distributed to students by diversity of perception. Due to the nature of students' learning pay their attention to new experiences and technology engagement. The challenge of preparing tomorrow citizens, we called for $21^{\text {st }}$ century learning skills which children will be faced with uncertainty situations in the future $[1,2]$. The power of information technology and internet influenced to curriculum and instructional strategies. Curriculum should not be recited only subject matters, but process and nature of $21^{\text {st }}$ century learners need to be designed for curriculum planning and its implementation [3, 4]. Technology for education can create curriculum integration among content, pedagogy and instructional practices [5-7]. The learning environments are changed and seem to be differed from than previous educational management. Technology and internet development allow students to face with new experiences and response to individual interests, individual differences, individual competency and information diversity.

Educators should plan and develop an appropriate curriculum to fit their nature of learning. Instruction should have technology integration as well as content and pedagogy needed. The integration is 
well-known concept, that is employed to education and educators should create it to schools. Technology is widely distributed to all sectors of education level and part of school development. Curriculum and instruction also need to teacher development through technology integration [8]. Teachers must know and understand how to use and imply as well as students' needs. Pre-service teacher, who is initial professional teachers and introduce necessary knowledge to their students. They can develop competencies to meet the requirements of professional standards in setting curriculum, instruction, assessment among content, learning materials, pedagogical activities and self-reflection of instruction [9-11].

Technological Pedagogical and Content Knowledge (TPACK) is now playing its role in the teacher development, teacher preparation program and teacher professionals [12, 13]. It is emerged and developed based on the concept of Pedagogical Content Knowledge (PCK), originated and extended from Shulman $[14,15]$ who characterize teacher knowledge to instructional explicitly by integrated pedagogy and content as well. PCK is an integration idea between content and pedagogy which teachers have to do in their classroom. However, the world is rapidly changing through the distribution of information and communication technology and also technology for education is widely developed. Educators concerned how to use and implement online learning and other technologies for education as well as nature of learners' learning in the current situations. TPACK is noted that integration technologies into content and instructional practices are suitable for new era of teaching and learning $[7,16]$.

TPACK is initially defined by Mishra and Koehler [17], to provide us about understanding teachers' use of technologies in teaching and learning. Technologies in education require teachers to possess necessary knowledge for learners' daily life. It is conception that connects the transformation of content and pedagogy with suitable technologies for learners. TPACK plays its role in effective teaching and learning in new era of teacher development, seven major knowledge components identify the nature of knowledge in TPACK. Knowledge includes concepts, laws, principles, theories, ideas, as well as established practices and approaches toward self-development $[14,18]$. It is important for teacher profession to engage students in the lesson and classroom activities [19, 20]. The teachers' idea and concept of classroom participation is generated by knowledge of pedagogy that is applicable to the teaching of specific content. PCK covers teaching techniques, learning process, curriculum, implementation, learning assessment and reporting [18].

TPACK is knowledge about the complex relations among technology, pedagogy and content that enable teachers to develop appropriate lesson, contextual classroom strategies and instructional practices through technology. It is a basis of effective instruction with suitable technology, requiring an understanding of the representation via technologies; pedagogical techniques as well as classroom management. Contents and contexts bring to students by educational technologies in appropriately to create students' learning fit in $21^{\text {st }}$ century learning environments [18]. We cannot reject technology from classroom or educational practices, but we have to know and understand how to use it in appropriateness [21]. TPACK is framework for teachers in technology integration, has been developed and distributed to teacher development. It requires teachers' competency in technology, pedagogy and content. To develop an understanding of the opportunities and challenges available in TPACK for teacher development and preparation program, it is considered to review the importance in developing an understanding as well.

Through the lens of teacher education reform ASEAN countries had launched project for teacher development in many various kinds of method. The purpose aims to promote teacher profession as twenty first century teachers. For those methods, concept of teacher education focus on technology education integrated in PCK or pedagogical content knowledge [14]. However, the concepts of PCK have been numerous terms to define the components of PCK for teaching and learning knowledge. Instructional practices use PCK gaining knowledge and necessary skills for students in which relevant to content, culture, context and psychological roles [22]. PCK help teachers to understand how to make an intersection among sets of content knowledge, the contexts of learning and pedagogical knowledge.

Additionally, previous studies reported that PCK related to teaching strategies, pedagogical issues in content area. Nuangchalerm [20] showed that PCK can help teacher students learn to be good teaching and good teacher based on pedagogical understandings. They have to know content as well as pedagogy uses to raise student's competence. Teacher students are taught to integrate pedagogy and content is the same way that they can implement teaching approaches. According to Shulman [15], teacher preparation programs should combine pedagogical knowledge and content knowledge to teaching and learning in appropriately. PCK is an ability to combine knowledge of a specific discipline with the science of teaching. It makes teachers do understand in content and transform into suitable instruction [14]. Linkages between content knowledge in the $21^{\text {st }}$ century is widely distributed and broadly presented. Teachers must change teaching behavior by not only emphasize on contents, but pedagogical issues should be implemented by creative classroom.

The influence of information technology and internet tend to be changed our learning environment. Content is less significant for teacher because internet can bring and present content in terms of multimedia 
and various kind of communication. Heibert [9] proposes framework for teacher preparation helping teacher students to develop competencies in setting instructional goals, evaluating student performance, hypothesizing connections between learning materials and self-reflection of instruction. The social changes and learning environments lead the trends of PCK to higher level of use. TPACK is proposed for education by integrating technology education into PCK due to the rapidly change in ICT and online learning influence to any classroom [23]. Its enhanced teacher education program and teacher development, its origin from information technology and $21^{\text {st }}$ century learners. Due to, it can be integrated in teacher preparation program. It was noted that TPACK is the ways of good teaching with technology and that it needs to help teachers have an understanding in professionals and integrating learning outcomes to authentic classroom.

TPACK has been used and distributed in the context of multiple teacher preparation and professional development programs. The interaction of all three knowledge domains is the integrated knowledge which teachers must understand and do for professional development. This study aims to analyse TPACK in ASEAN education and make a linkage TPACK of pre-service science teachers in the school practicum. The findings will be used for teacher preparation program and provides a basis for understanding pre-service teacher knowledge that supports successful technology integration into classroom. Educators can be used information to develop teacher education and programs for TPACK distribution.

\section{RESEARCH METHOD}

\subsection{ASEAN literatures about TPACK}

The study employed a systematic literature review, TPACK and teacher preparation program were framework. The ASEAN Citation Index (ACI) database was used to search for articles using the search terms "TACK" because it was widely used term in general studies. The ACI database was selected because it does collect articles in field of education. ACI is an indexing of central regional database in ASEN countries, it was designed and set up to index all the bibliographic records and the citations of all quality ASEAN research in the ASEAN scholarly journals. Furthermore, the number of publications, the citations, the Hindex and other bibliometric indexes of ASEAN research output plays a major role in integrating of ASEAN research performance evaluation in the national, regional and international levels [24].

\subsubsection{Procedural searching}

Data were accessed through the ACI (http://www.asean-cites.org) and then filled the search terms for making consideration. Researcher specifies the search terms to retrieve a high number of academically relevant related articles. The criteria in selecting article set through full text available on ACI. The search was carried out on December 2018. Researcher eliminated these non-relevant search matches therefore narrowed down the results to 11 articles.

\subsubsection{Data analysis}

The articles were systematic reviewed, the 6 selected articles. Steps of article selection were used for screening related issues. Article was categorized into content that relevant to descriptions of TPACK. All articles that did not include at least one of these terms were excluded from the following analysis, which reduced the number of selected articles to 11 . The terms which describing TPACK were gently extracted from each article. All of articles in which match terms were collected from the articles selected for the analysis and sources outside the critical articles. The article analysis involved 11 TPACK issues, a specific term was not defined by the researcher, the defined terms of each article was analysed and classified based on research framework.

\subsection{Empirical TPACK of pre-service teachers}

This study employed survey method and qualitative investigation the integration technology of preservice teachers into their classroom through TPACK.

\subsubsection{Context of the study and participants}

Seven Thai pre-service science teachers participated in the study. They were $5^{\text {th }}$ year-teacher student who had to pay attention with school practices as well as professional standards regulation [25]. They have to make decision accurately and appropriately based on teacher preparation program, decision making in classroom management, use technology and learning materials and evaluate learning progress of students. They had responsibilities as above in 4 different schools. Five females and 2 males enrolled in teacher preparation program in general science. At the time of the study, the participants were enrolled in the Internship 1 and Internship 2, a six-credit course in each semester, academic year 2018. Courses emphasizing 
on school practicum, were designed to improve teacher profession, pedagogical skills, managerial skills of instruction and technology integration in classroom.

\subsubsection{TPACK self-assessment}

To measure TPACK and technology integration, TPACK questionnaire was administered via Google Forms system. The lesson plan was studied and report in descriptive analysis. TPACK questionnaire was surveyed through 36 items. Participants rated their perception with each item on a 5-point Likert scale (5 $=$ Strongly Agree, 4 = Agree, $3=$ Neutral, $2=$ Disagree, $1=$ Strongly Disagree). The measure of TPACK domains used in this study represents participants' self-assessment of their knowledge.

\subsubsection{Procedure}

TPACK questionnaire was administered via an online survey system in the last week semester that pre-service teachers had practicum in the course of Internship 2. A hyperlink to the survey and description of the study were available sent directly to panel respondents. Then, data were analyzed by mean, standard deviation and transcribed based on criteria of perception level. Data were shown for presenting how preservice science teachers perceived TPACK in their different opinions by indicating into 5 levels of mean for interpreting: Highest (4.51-5.00), High (3.51-4.50), Medium (2.51-3.50), Low (1.51-2.50) and Lowest (1.00$1.50)$.

\section{RESULTS AND DISCUSSION}

\subsection{ASEAN literatures about TPACK}

TPACK is important concept of teaching in the $21^{\text {st }}$ century learning because knowledge is not isolated, technology links our world together, integration makes quality of education, global village create one and less environmental destruction. Teachers have to implement technology, pedagogy and content based on holistic views [26]. Blending three forms of knowledge help teachers make different teaching and learning skills. Due to, world is rapidly changed as technology and internet as key factors to new learning environments. If teachers ignore or less technology education, then teachers have only content it seems to be traditional teaching [10]. Pedagogy can build students understand concept when concept is generalized and simplified by effective presentation. However, internet can give a variety of teaching tools to all students by multimedia, students use applications based on their interests, individual response and individual differences. TPACK framework that teachers need to have deep understandings technology, pedagogy and content knowledge, it is the complex form of integration in content (CK), pedagogy (PK) and technology (TK) knowledge. Also, they can implement these forms of knowledge into classroom as well as professional teachers.

The analysis of TPACK in ASEAN literature, knowledge in the $21^{\text {st }}$ century is not isolated but it needs integration. Especially, information and communication technology is now expanding, plays it roles important to all areas of study. Teachers have to engage technology and learning skills which response to learners' behaviours [27]. The instruction and classroom practices in the past ignore how to integrate technology for education or less interests. Teachers focus on content and subject matters, due to the process of teaching and learning base on recitation and content recognition. In addition, teachers have less pedagogical strategies because less classroom activities. However, this era the educational environment is rapidly changed and adopt technology education to curriculum.

The content knowledge is now uncertainty because information technology transferred big data and over load information to all. Content seem to be old as well as technology changed. Teachers have to adapt and apply instructional practices themselves in various kinds of teaching methods and technology uses [28]. Knowledge of technology, pedagogy and content are importance for effective teachers. TPACK is a framework that teachers need to have deep understandings of three components of knowledge. Technology, pedagogy and content knowledge are emergent form of knowledge that it describes teacher needs by effective technology integration. That is, TPACK is the complex form of integration in content (CK), pedagogy (PK) and technology (TK) knowledge.

TPACK is elaborated from Shulman [14] to focus effective teaching through the integration of pedagogy knowledge and content knowledge. Then, Mishra and Khoeler [17] developed three domains of knowledge and called technological, pedagogical and content knowledge. Accordingly, teachers must pay more attention to pedagogy and content, incorporating technological usage. They require the use of educational technology supporting learning behaviour which allows students to engage in nature of learning [29]. In addition, there are three components: content, pedagogy and technology. These three components form the core of the technological, pedagogical content knowledge [17, 18]. TPACK is invited to education, teaching requires effective teachers who understand the content they want to teach, also crucial 
pedagogy and suitable technology that can support learning of students. TPACK is knowledge that required teachers integrate appropriate technology into teaching and content [30]. Koehler and Mishra [18] propose that the integrating knowledge of technology, pedagogy and content are significant components to effective teaching in modern era of learning. TPACK is answer for professional teacher, useful framework for thinking about what knowledge teachers must learn to have and can integrate technology into teaching.

ASEAN countries employed TPACK into curriculum and school practices. Technology is not most the component, but it is important for teacher to design lesson plan and instructional activities. Technology engage students with the lesson, communicate in diversely, multi-representation in teaching and learning and create communicative skills. A variety of technology help students learn to change their cognitive skills and other learning behaviours for $21^{\text {st }}$ century classroom i.e. Youtube, Google applications, Line, Facebook and so on. Content is uploaded, but the reliability is required a critical decision. Teachers have to design content with technology for individual interests as well as smart technology tools allowed. Video on demand is tricky that teachers play their role model by online lesson. Authentic teaching, authentic learning and authentic assessment are strongly needed to all teachers.

However, technology and its infrastructures need to be prepared, teachers have to join professional program to implement TPACK which suitable for their teaching. Knowledge in content seem to be strong, but technology integrated teaching required much more than those traditional teaching. They have to develop training courses via pedagogical strategies which response to $21^{\text {st }}$ century learners. The literatures of TPACK in ASEAN education will be linked to practices, empirical TPACK of pre-service teachers is investigated.

\subsection{Empirical TPACK in school practicum}

The level of TPACK of 7 pre-service science teachers, it can be shown that they had high level at all knowledge domains. They had domains of knowledge in TCK highest than those TK, TPK, TCK, PCK, PK and $\mathrm{CK}$ in the following. These mean they had knowledge in technology integration in school practices as well as program of study designed. Also, they can use technology to help learner access lesson by engaging technologies in different methods. The TPACK of pre-service teachers by exploratory study can be shown in Table 1.

Table 1. Self-assessment of TPACK of pre-service teachers

\begin{tabular}{cccc}
\hline TPACK item & Mean & SD & Level of opinion \\
\hline TK & 4.17 & 0.56 & High \\
CK & 3.86 & 0.45 & High \\
PK & 3.88 & 0.50 & High \\
PCK & 3.89 & 0.42 & High \\
TCK & 3.93 & 0.60 & High \\
TPK & 4.12 & 0.48 & High \\
TPACK & 4.14 & 0.47 & High \\
\hline
\end{tabular}

All knowledge domains showed that pre-service teachers understand technology integration and bring to classroom learning environments. They had high level of technology, pedagogy and content knowledge, but content knowledge seems to be less than those other domains. They also express item to the technological skills for instruction and design and develop technologies for teaching and learning process are at lowest mean score for technology integration.

Mishra and Khoeler [17] suggested that teachers must pay more attention to technology, especially modern technology, internet tools, multimedia for edutainment and many forms of technology. Social networking can use in TPACK framework because collaborative learning is now explosive. The collaboration makes effective communication via internet of learning, but thinking about content is critical and analytical decision. Technology is tool to engage and transfer information to students. TPACK is essential framework that teachers have to know, understand and use the integration as well as students' interests [8]. Koehler and Mishra [18] argue that TPACK help teachers understand and can use these forms of knowledge into teaching and learning process. Teachers need to know what and how they implement technology in the unique contexts within their classroom in contexts. TPACK in ASEAN countries seem not to be different, but technology is a basic consideration in each country. The development of TPACK in ASEAN is influenced by national policy of education, technology infrastructures, internet readiness and teacher competency in lessonintegrated design. The quality of teaching depends on classroom contexts and the way in what teachers taught. The challenges of TPACK framework can be considered by teachers' competencies in technology engagement and implication.

Technology is vital factor that moving forward together between content and pedagogy, students interested in the moment of multi-representation. The discussion in this paper explored teaching by TPACK, 
focused on ICT use and its application to facilitate learning behaviour. Teachers need to have strong content; some reports found that teachers less understanding and implementing suitable technology into their instructional practices $[11,31,32]$. At this reason, school and administrator should have training course or professional development program helping them integrate technology, pedagogy and subject matter as well as integration of teaching defined. Although ICT is largely used, teachers have to learn new technology and develop teaching skills as much as students' needs. Design thinking should be used for classroom activitiesbased instruction in preparing teachers in TPACK. However, each country needs to set the goal of educational management by helping teachers know, understand and can use TPACK in teaching process [33].

Especially, teacher preparation program or pre-service teachers who are young blood of schooling, familiar with new technology, eager to learn innovation and empower TPACK to $21^{\text {st }}$ century education. The empirical study of TPACK in pre-service science teachers showed that all knowledge domains showed that they understand technology integration and bring different methods and ideas to classroom learning environments. However, they had level of opinions is at high level of TPACK, but technology, pedagogy and content knowledge seem to be varied. Technology integration in school practicum needs them to have technological skills for instruction, design and develop technologies for teaching and learning process $[8,23,30]$. Teacher preparation program need to be aware teacher competency and embedding TPACK into program of study. While the nature of learners' learning is changed, teachers should be adapted teaching strategies and they can invite technology for education for effective teaching $[34,35]$.

\section{CONCLUSION}

Technological Pedagogical and Content Knowledge (TPACK) is important for teacher development program, the study showed interestingly explored by pre-service teachers had their TPACK is at high level. They had competent to instructional practices in TPACK about technology integration through various kinds of content and pedagogy. Teacher preparation program should design and embed TPACK in curriculum and instruction.

\section{ACKNOWLEDGEMENT}

This research project was financially supported by Mahasarakham University (Fast Track 2020).

\section{REFERENCES}

[1] Akarawang, C. Kidrakran, P. and Nuangchalerm, P., "Enhancing ICT competency for teachers in the Thailand basic education system," International Education Studies, vol. 8, no. 6, pp. 1-8, 2015.

[2] Hong, H.Y. Lin, P.Y. Chai, C.S. Hung, G.T. and Zhang Y., "Fostering design-oriented collective reflection among preservice teachers through principle-based knowledge building activities," Computers and Education, vol. 130, pp. 105-120, Mar. 2019.

[3] Williams-Diehm, K.L. Miller, C.R. Sinclair, T.E. and Wronowski, M.L., "Technology-based employability curriculum and culturally diverse learners with disabilities," Journal of Special Education Technology, vol. 33, no. 3, pp. 159-170, 2018.

[4] Doyle, A. Seery, N. Canty, D. and Buckley, J., "Agendas, influences and capability: Perspectives on practice in design and technology education," International Journal of Technology and Design Education, vol. 29, no. 1, pp. 143-159, 2019.

[5] Chuang, H.H. Weng, C.Y. and Huang, F.C., "A structure equation model among factors of teachers' technology integration practice and their TPACK," Computers and Education, vol 86, pp. 182-191, Aug. 2015.

[6] Kennedy J., "Using TPACK as a scaffold to self-assess the novice online teaching experience," Distance Education, vol. 36, no. 1, pp. 148-154, 2015.

[7] De Rossi M. and Trevisan, O., "Technological Pedagogical Content Knowledge in the literature: how TPACK is defined and implemented in initial teacher education," Italian Journal of Educational Technology, vol 26, no. 1, pp. 7-23, 2018 .

[8] Tondeur, J. van Braak, J. Ertmer, P.A. and Ottenbreit-Leftwich, A., "Understanding the relationship between teachers' pedagogical beliefs and technology use in education: A systematic review of qualitative evidence," Educational Technology Research and Development, vol. 65, no. 3, pp. 555-575, 2017.

[9] Hiebert, J. Morris, A.K. Berk, D. and Jansen A., "Preparing teachers to learn from teaching," Journal of Teacher Education, vol. 58, no. 1, pp. 47-61, 2007.

[10] Martin, B. "Successful implementation of TPACK in teacher preparation programs," International Journal on Integrating Technology in Education, vol. 4, no. 1, pp. 17-26, 2015.

[11] Tondeur, J. Pareja, R.N. van Braak, J. Voogt, J. and Prestridge, S., "Preparing beginning teachers for technology integration in education: ready for take-off?” Technology, Pedagogy and Education, vol. 26, no. 2, pp. 157-177, 2017.

Int. J. Eval. \& Res. Educ. Vol. 9, No. 4, December 2020: 993 - 999 
[12] Gill, L. and Dalgarno, B., "A qualitative analysis of pre-service primary school teachers' TPACK development over the four years of their teacher preparation programme," Technology, Pedagogy and Education, vol 26, no. 4, pp. 439-456, 2017.

[13] Olofson, M.W. Swallow, M.J. and Neumann, M.D., "TPACKing: A constructivist framing of TPACK to analyze teachers' construction of knowledge," Computers and Education, vol. 95, pp. 188-201, Apr. 2016.

[14] Shulman, L.S. "Those who understand: Knowledge growth in teaching," Educational Researcher, vol. 15, no. 2, pp. 4-14, 1986.

[15] Shulman, L.S., "Knowledge and teaching: Foundations of the new reform," Harvard Educational Review, vol. 57, no. 1, pp. 1-23, 1987.

[16] Erduran, A. and Ince, B., "Identifying mathematics teachers' difficulties in technology integration in terms of Technological Pedagogical Content Knowledge (TPACK)," International Journal of Research in Education and Science, vol. 4, no. 2, pp. 555-576, 2018.

[17] Mishra, P. and Koehler, M., "Technological Pedagogical Content Knowledge: A framework for teacher knowledge," Teachers College Record, vol. 108, no. 6, pp. 1017-1054, 2006.

[18] Koehler, M. and Mishra, P., "What is technological pedagogical content knowledge?" Contemporary Issues in Technology and Teacher Education, vol. 9, no. 1, pp. 60-70, 2019.

[19] Nuangchalerm, P., "In-service science teachers' pedagogical content knowledge," Studies in Sociology of Science, vol. 2, no. 2, pp. 33-37, 2011.

[20] Nuangchalerm, P., "Enhancing pedagogical content knowledge in preservice science teachers," Higher Education Studies, vol. 2, no. 2, pp. 66-71, 2012.

[21] Rosenberg, J.M. and Koehler, M.J., "Context and technological pedagogical content knowledge (TPACK): A systematic review," Journal of Research on Technology in Education, vol. 47, no. 3, pp. 186-210, 2015.

[22] Gess-Newsome, J., "Pedagogical content knowledge: An introduction and orientation," in Examining pedagogical content knowledge, pp. 3-17. Springer: Dordrecht, 1999.

[23] Koh, J.H.L Chai, C.S. Benjamin, W. and Hong, H.Y., "Technological Pedagogical Content Knowledge (TPACK) and design thinking: A framework to support ICT lesson design for $21^{\text {st }}$ century learning," The Asia-Pacific Education Researcher, vol. 24, no. 3, pp. 535-543, 2015.

[24] Sombatsompop, N. Premkamolnetr, N. Markpin, T. Ittiritmeechai, S. Wongkaew, C. Yochai, W. Ratchatahirun, P. and Beng, L.I., "Viewpoints on synergising ASEAN academic visibilities through research collaboration and the establishment of an ASEAN Citation Index Database 1," Asia Pacific Viewpoint, vol. 52, no. 2, pp. 207-218, 2011.

[25] Prachagool, V. Nuangchalerm, P. Subramaniam, G. and Dostál, J., "Pedagogical decision making through the lens of teacher preparation program," Journal for the Education of Gifted Young Scientists, vol. 4, no. 1, pp. 41-52, 2016.

[26] Swallow, M.J, and Olofson, M.W., "Contextual understandings in the TPACK framework," Journal of Research on Technology in Education, vol. 49, no. 3-4, pp. 228-244, 2017.

[27] Clark, C.A. Phenomenological study of the impact of pre-service and in-service training regarding the integration of twenty-first century technologies into selected teachers' instruction. Virginia: Liberty University, 2013.

[28] Denby, D, and Holman, J., ICT in support of science education. York: University of York, 2002.

[29] Collis, B. and Moonen, J., "Flexible learning in a digital world," Open Learning: The Journal of Open, Distance and e-Learning, vol. 17, no. 3, pp. 217-230, 2002.

[30] Schmidt, D.A. Baran, E. Thompson, A.D. Mishra, P. Koehler, M.J. and Shin, T.S., "Technological pedagogical content knowledge (TPACK) the development and validation of an assessment instrument for preservice teachers," Journal of Research on Technology in Education, vol. 42, no. 2, pp. 123-149, 2009.

[31] Evans, M.A. Nino, M. Deater-Deckard, K. and Chang, M., "School-wide adoption of a mathematics learning game in a middle school setting: Using the TPACK framework to analyze effects on practice" The Asia-Pacific Education Researcher, vol. 24, no. 3, pp. 495-504, 2015.

[32] Finger, G. Romeo, G. Lloyd, M. Heck, D. Sweeney, T. Albion, P. and Jamieson-Proctor, R., "Developing graduate TPACK capabilities in initial teacher education programs: insights from the teaching teachers for the future project," The Asia-Pacific Education Researcher, vol. 24, no. 3, pp. 505-513, 2016.

[33] Blau, I. and Shamir-Inbal, T., "Digital competences and long-term ICT integration in school culture: The perspective of elementary school leaders," Education and Information Technologies, vol. 22, no. 3, pp. 769-787, 2017.

[34] Prachagool, V. and Nuangchalerm, P., "Investigating the nature of science: An empirical report on the teacher development program in Thailand," Jurnal Pendidikan IPA Indonesia, vol. 8, no. 1, pp. 32-38, 2019.

[35] Prachagool, V. and Nuangchalerm, P., "Investigating understanding the nature of science," International Journal of Evaluation and Research in Education, vol. 8, no. 4, pp. 719-725, 2019. 